\title{
Peningkatan Hasil Belajar Siswa Tentang Pengaruh Perubahan Lingkungan Terhadap Daratan Melalui Media Kartu
}

\author{
N. Ade Ika \\ SD Negeri Kebagusan 02 Pagi Kecamatan Pasar Minggu Jakarta Selatan \\ ditaadilla@gmail.com
}

\begin{abstract}
Increasing the ability of students in learning the influence of environmental change on land needs to be attempted as early as possible, because this ability is very useful in everyday life. In this case the teacher has the greatest responsibility, because it is directly in contact with students. Therefore, teachers are required to carry out various variations in the learning process in order to attract students' interest. One way to improve this ability is by applying learning models using card media. Based on the preliminary survey by researchers, the learning method used in the Natural Sciences lesson at Kebagusan 02 Pagi Public Elementary School, Pasar Minggu South Jakarta District, was still dominated by the lecture method accompanied by assignments. Learning outcomes of Natural Sciences on the subject of the Effect of Environmental Change on Mainland fourth grade students of SD Negeri Kebagusan 02 Pagi, Pasar Minggu South Jakarta District for the 2016/2017 school year is not satisfactory because the average is still below the Minimum Completeness Criteria (KKM) in Science subjects Natural. Therefore, the classroom action research is carried out with the main objective to improve student learning outcomes about the effect of environmental changes on land through card media for fourth grade students of SD Negeri Kebagusan 02 Pagi, Pasar Minggu, South Jakarta. This research was conducted on 33 students using classroom action research methods (classroom action research). The results of the study with several actions showed an increase in student participation in the learning process from the first cycle to the second cycle, from the category of being quite good. Students' understanding of the material "Influence of Environmental Change on Mainland" in class IV SD Kebagusan 02 Pagi Subdistrict Pasar Minggu South Jakarta has increased. The average value of student learning outcomes based on the results of student evaluation in the first cycle of meeting 1 obtained an average value of 62.73, cycle I meeting 2 with an average of 68.79, cycle II meeting 1 increased to 74.85 and in the second cycle of Meeting 2, the average value was 80.76 .
\end{abstract}

Keywords : student learning outcomes, environmental changes, card media.

\begin{abstract}
Abstrak : Peningkatan kemampuan siswa dalam pembelajaran pengaruh perubahan lingkungan terhadap daratan perlu diupayakan sedini mungkin, sebab kemampuan ini sangat berguna dalam kehidupan sehari-hari. Dalam hal ini guru memiliki tanggung jawab yang paling besar, karena langsung bersentuhan dengan siswa. Oleh karena itu, guru dituntut untuk melakukan berbagai variasi dalam proses pembelajaran agar dapat menarik minat siswa. Salah satu cara meningkatkan kemampuan tersebut adalah dengan penerapan model pembelajaran dengan menggunakan media kartu. Berdasarkan survey pendahuluan oleh peneliti, metode pembelajaran yang digunakan dalam pelajaran Ilmu Pengetahuan Alam di SD Negeri Kebagusan 02 Pagi Kecamatan Pasar Minggu Jakarta Selatan, masih didominasi metode ceramah disertai dengan penugasan. Hasil belajar Ilmu Pengetahuan Alam pada pokok bahasan Pengaruh Perubahan Lingkungan Terhadap Daratan siswa kelas IV SD Negeri Kebagusan 02 Pagi Kecamatan Pasar Minggu Jakarta Selatanuntuk tahun pelajaran 2016/2017 belum memuaskan karena rata-rata masih di bawah Kriteria Ketuntasan Minimal (KKM) mata pelajaran Ilmu Pengetahuan Alam. Oleh karena itu, maka dilakukan penelitian tindakan kelas dengan tujuan utama untuk meningkatkan hasil belajar siswa tentang pengaruh perubahan lingkungan terhadap daratan melalui media kartu pada siswa Kelas IV SD Negeri Kebagusan 02 Pagi Kecamatan Pasar Minggu Jakarta Selatan. Penelitian ini dilakukan terhadap 33 siswa dengan menggunakan metode penelitian tindakan kelas (classroom action research). Hasil penelitian dengan beberapa tindakan, menunjukkan adanya peningkatan partisipasi siswa dalam proses pembelajaran mulai siklus pertama sampai dengan siklus kedua, dari kategori cukup menjadi baik. Pemahaman siswa tentang materi "Pengaruh Perubahan Lingkungan terhadap Daratan" di kelas IV SD Negeri Kebagusan 02 Pagi Kecamatan Pasar Minggu Jakarta Selatan mengalami peningkatan. Nilai rata-rata hasil belajar siswa yang didasarkan pada hasil evaluasi belajar siswa pada siklus I pertemuan 1 diperoleh nilai rata-rata 62,73, siklus I pertemuan 2 dengan rata-rata 68,79, siklus II pertemuan 1 meningkat menjadi 74,85 dan pada siklus II Pertemuan 2 diperoleh nilai rata-rata 80,76.
\end{abstract}

Kata Kunci - Hasil belajar siswa, perubahan lingkungan, media kartu. 


\section{Pendahuluan}

Menurut Peraturan Menteri Pendidikan Nasional Nomor 22 tahun 2006, mata pelajaran Ilmu Pengetahuan Alam (Sains) untuk Sekolah Dasar bertujuan menanamkan kebiasaan berpikir dan berperilaku ilmiah yang kritis, kreatif, dan mandiri. Melalui kebiasan dan perilaku tersebut, siswa Sekolah Dasar diharapkan mengenal, menyikapi, dan mengapresiasi ilmu pengetahuan dan teknologi. Kedua tujuan ini, secara jelas menyiratkan adanya sebuah proses yang dijalankan dan produk yang dihasilkan.

Dalam Peraturan Menteri Pendidikan Nasional Nomor 23 tahun 2006, dikemukakan bahwa Standar Kompetensi Lulusan untuk mata pelajaran IPA adalah sebagai berikut,

1. Melakukan pengamatan terhadap gejala alam dan menceritakan hasil pengamatannya secara lisan dan tertulis.

2. Memahami penggolongan hewan dan tumbuhan, serta manfaat hewan dan tumbuhan bagi manusia, upaya pelestariannya, dan interaksi antara makhluk hidup dengan lingkungannya.

3. Memahami bagian-bagian tubuh pada manusia, hewan, dan tumbuhan, serta fungsinya dan perubahan pada makhluk hidup.

4. Memahami beragam sifat benda hubungannya dengan penyusunnya, perubahan wujud benda, dan kegunaannya.

5. Memahami berbagai bentuk energi, perubahan, dan manfaatnya.

6. Memahami matahari sebagai pusat tata surya, kenampakan dan perubahan permukaan bumi, dan hubungan peristiwa alam dengan kegiatan manusia.

Berdasarkan Standar Kompetensi Lulusan yang dikemukakan, tampak bahwa adanya suatu keterampilan proses, yakni pengamatan dan produk yang merupakan tingkatan proses kognitif understanding (memahami).

Oleh karena itu, perlu adanya sebuah proses yang mendukung tercapainya produk tersebut. Proses tersebut telah dikemukakan dalam Peraturan Menteri Pendidikan Nasional Nomor 22 tahun 2006 yakni proses yang menekankan agar siswa memiliki kebiasaan berpikir dan berperilaku ilmiah yang kritis, kreatif, dan mandiri. Melalui proses inilah akan dicapai produk yang tidak hanya menjadikan siswa mengingat fakta-fakta tetapi juga memahami pengetahuan melalui aktivitas-aktivitas ilmiah.

Amanat yang tercantum dalam Peraturan Menteri Pendidikan Nasional Nomor 22 tahun 2006 dan Peraturan Menteri Pendidikan Nasional Nomor 23 tahun 2006 tersebut, menunjukkan bahwa Ilmu Pengetahuan Alam haruslah dibelajarkan sesuai dengan hakikatnya, yakni sebagai cara untuk menyelidiki dan sebagai kumpulan pengetahuan. Mulyana (2008:16) menyatakan bahwa:

"Pembelajaran IPA sebagai media pengembangan potensi siswa SD seharusnya didasarkan pada karakteristik psikologis anak, memberikan kesenangan bermain dan kepuasan intelektual bagi mereka dalam membongkar misteri, seluk beluk dan teka-teki fenomena alam di sekitar dirinya".

Berdasarkan survey pendahuluan oleh peneliti, metode pembelajaran yang digunakan dalam pelajaran Ilmu Pengetahuan Alam di SD Negeri Kebagusan 02 Pagi Kecamatan Pasar Minggu Jakarta Selatan, masih didominasi metode ceramah disertai dengan penugasan. Pembelajaran yang demikian pada umumnya membuat siswa merasa jenuh dan bosan dengan mata pelajaran Ilmu Pengetahuan Alam, sehingga pada akhirnya hasil belajar mata pelajaran Ilmu Pengetahuan Alam menjadi rendah. Hasil belajar Ilmu Pengetahuan Alam pada pokok bahasan Pengaruh Perubahan Lingkungan Terhadap Daratan siswa kelas IV SD Negeri Kebagusan 02 Pagi Kecamatan Pasar Minggu Jakarta Selatan untuk tahun pelajaran 2016/2017 belum memuaskan karena rata-rata masih di bawah Kriteria Ketuntasan Minimal (KKM) mata pelajaran Ilmu Pengetahuan Alam.

Berkenaan dengan hal tersebut, maka penggunaan media pembelajaran yang tepat menjadi daya dukung utama bagi guru sebagai upaya untuk menciptakan suasana belajar siswa secara aktif. Menurut Siddiq (2008 : 21) menyatakan bahwa:

"Media pembelajaran sangat diperlukan dalam proses kegiatan pembelajaran. Beberapa fungsi dari media pembelajaran dalam proses komunikasi pembelajaran diantaranya sebagai berikut:

1. Berperan sebagai komponen yang membantu mempermudah /memperjelas materi atau pesan pembelajaran dalam proses pembelajaran;

2. Membuat pembelajaran menjadi lebih menarik;

3. Membuat pembelajaran lebih realistis/objektif;

4. Menjangkau sasaran yang luas;

5. Mengatasi keterbatasan jarak dan waktu, karena dapat meampilkan pesan yang berada di luar ruang kelas dan dapat menampilkan informasi yang terjadi pada masa lalu, mungkin juga masa yang akan datang.

6. Mengatasi informasi yang bersifat membahayakan, gerakan rumit, objek yang sangat besar dan sangat kecil, semua dapat disajikan menggunakan media yang telah dimodifikasi.

7. Menghilangkan verbalisme yang hanya bersifat kata-kata."

Berdasarkan uraian latar belakang di atas maka peneliti tertarik untuk melakukan penelitian dengan judul: "Peningkatan Hasil Belajar Siswa tentang Pengaruh Perubahan Lingkungan Terhadap Daratan Melalui Media Kartu (Penelitian Tindakan Kelas pada Pembelajaran Ilmu Pengetahuan Alam di Kelas IV SD Negeri Kebagusan 02 Pagi Kecamatan Pasar Minggu Jakarta Selatan Tahun Ajaran 2016/2017 Semester II)." 
Berdasarkan uraian latar belakang masalah di atas, maka masalah pokok yang akan diteliti dalam penelitian ini sebagai berikut:

1. Bagaimana peningkatan kemampuan guru menyusun perencanaan pembelajaran Ilmu Pengetahuan Alam pada pokok bahasan pengaruh perubahan lingkungan terhadap daratan melalui penggunaan media kartu di kelas IV SD Negeri Kebagusan 02 Pagi Kecamatan Pasar Minggu Jakarta Selatan?

2. Bagaimana peningkatan kemampuan guru mengelola pembelajaran Ilmu Pengetahuan Alam pada pokok bahasan pengaruh perubahan lingkungan terhadap daratan melalui penggunaan media kartu di kelas IV SD Negeri Kebagusan 02 Pagi Kecamatan Pasar Minggu Jakarta Selatan?

3. Bagaimana peningkatan hasil belajar siswa pada pembelajaran Ilmu Pengetahuan Alam tentang pengaruh perubahan lingkungan terhadap daratan melalui penggunaan media kartu di kelas IV SD Negeri Kebagusan 02 Pagi Kecamatan Pasar Minggu Jakarta Selatan?

Adapun tujuan dari penelitian ini adalah:

1. Untuk meningkatkan kemampuan guru menyusun perencanaan pembelajaran Ilmu Pengetahuan Alam pada pokok bahasan pengaruh perubahan lingkungan terhadap daratan melalui penggunaan media kartu di kelas IV SD SD Negeri Kebagusan 02 Pagi Kecamatan Pasar Minggu Jakarta Selatan.

2. Untuk meningkatkan kemampuan guru mengelola pembelajaran Ilmu Pengetahuan Alam pada pokok bahasan pengaruh perubahan lingkungan terhadap daratan melalui penggunaan media kartu kelas IV SD Negeri Kebagusan 02 Pagi Kecamatan Pasar Minggu Jakarta Selatan.

3. Untuk meningkatkan hasil belajar siswa pada pembelajaran Ilmu Pengetahuan Alam tentang pengaruh perubahan lingkungan terhadap daratan melalui penggunaan media kartu di kelas IV SD Negeri Kebagusan 02 Pagi Kecamatan Pasar Minggu Jakarta Selatan.

Manfaat yang diharapkan dari hasil penelitian ini adalah sebagai berikut:

1. Bagi Sekolah

a. Dapat menentukan strategi yang tepat dalam memilih media pembelajaran yang sesuai dengan tujuan pembelajaran.

b. Memberikan sumbangan pemikiran bagi pihak sekolah dalam meningkatkan aktifitas pembelajaran sehingga mampu meningkatkan mutu pembelajaran.

2. Bagi Guru

a. Menambah wawasan dan pengetahuan bagi guru dengan menggunakan media pembelajaran dalam meningkatkan aktifitas pembelajaran. b. Menambah variasi dalam kegiatan pembelajaran supaya tidak merasa jenuh dalam belajar Ilmu Pengetahuan Alam.

3. Bagi Siswa

a. Dapat menumbuhkan dan mengembangkan motivasi dan keaktifan belajar siswa dalam mempelajari Ilmu Pengetahuan Alam.

b. Dapat membantu meningkatkan hasil belajar siswa pada konsep pengaruh perubahan lingkungan terhadap daratan dan meningkatkan peran aktif siswa.

\section{METODE PENELITIAN}

\section{A. Setting dan Subjek Penelitian}

Penelitian ini dilaksankan di SD Negeri Kebagusan 02 Pagi Kecamatan Pasar Minggu Jakarta Selatan. Peneliti memilih lokasi ini dikarenakan merupakan tempat peneliti bertugas sebagai pengajar, sehingga memudahkan peneliti untuk melakukan penelitian..

Subjek dari penelitian ini adalah siswa kelas IV SD Negeri Kebagusan 02 Pagi Kecamatan Pasar Minggu Jakarta Selatan tahun ajaran 2016/2017. Adapun jumlah siswa yang menjadi subyek penelitian ini sebanyak 33 orang terdiri dari 26 orang siswa laki-laki dan 7 siswa perempuan.

Kegiatan Penelitian Tindakan Kelas ini akan dilakukan dalam pembelajaran Ilmu Pengetahuan Alam di Kelas IV SD Negeri Kebagusan 02 Pagi Kecamatan Pasar Minggu Jakarta Selatan, semester genap tahun 2017 dengan topik pengaruh perubahan lingkungan terhadap daratan. Penelitian ini dilaksanakan sebanyak 2 siklus masing-masing 2 pertemuan. Pelaksanaan kegiatan dapat dilaksanakan sebagai berikut:

1. Persiapan penelitian tanggal 06 s.d. 27 Maret 2017

2. Perijinan peneltian dari Kepala Sekolah 30 Maret 2017

3. Observasi awal penelitian 03 April 2017

4. Pelaksanaan penelitian sebagai berikut:

- Siklus I pertemuan 1 dilaksanakan tanggal 04 April 2017,

- Siklus I pertemuan 2 dilaksanakan tanggal 11 April 2017,

- $\quad$ Siklus II pertemuan 1 dilaksanakan tanggal 18 April 2017,

- Siklus II pertemuan 2 dilaksanakan tanggal 25 April 2017,

5. Pengolahan dan penggandaan hasill penelitian tanggal 02 s.d. 23 Mei 2017

6. Seminar hasil penelitian tanggal 27 Mei 2017

7. Pelaporan hasil penelitian tanggal 30 Mei 2017

\section{B. Prosedur Penelitian}

Prosedur penelitan yang dilakukan dalan penelitian ini diantaranya adalah refleksi awal, perencanaan tindakan peneitian, pelasanaan tindakan penelitian, dan refleksi. 


\section{Teknik dan Instrumen Pengumpulan Data}

Adapun jenis data yang terkumpul dalam penelitian ini terdiri dari :

\section{Sumber Data}

Sumber data dalam penelitian ini adalah siswa, tim peneliti, dan proses pembelajaran.

2. Jenis Data dan Cara Pengumpulannya

Data utama yang akan dikumpulkan serta cara pengumpulannya selama pelaksanaan Penelitian Tindakan Kelas

\section{Teknik Analisis Data}

Teknik analisis data digunakan ada yang bersifat kualitatif dan kuantitatif. Data yang diperoleh yang terdiri dari hasil belajar, rencana terhadap pelaksanaan pembelajaran dengan menggunakan media kartu .

Temuan-temuan data dalam penelitian diinterpretasikan dengan merujuk kepada acuan teoritik, norma-norma praktis yang disepakati atau didasarkan intuisi guru mengenai situasi pembelajaran yang baik, tentang media kartu sehingga diperoleh suatu kerangka referensi yang dapat memberikan makna terhadapnya.

Pembelajaran dan hasil observasi dikategorikan dan diklasifikasikan berdasarkan analisis, kemudian ditafsirkan dan disajikan secara aktual dan sistematis dalam keseluruhan permasalahan.

\section{E. Indikator Keberhasilan}

Tolok ukur keberhasilan yang dilakukan oleh guru untuk peningkatan pemahaman dan hasil belajar siswa melalui media kartu adalah sebagai berikut :

1. Bagi guru yang mampu menunjukkan kinerja baik jika :

1) Sekurang-kurangnya $80 \%$ dari jumlah indikator yang telah ditetapkan.

2) Indikator aspek kinerja guru dalam menyusun perencanaan pembelajaran dan dalam melaksanakan media kartu .

3) Sekurang-kurangnya $80 \%$ hasil belajar siswa dalam pembelajaran.

2. Bagi siswa yang mampu menunjukkan pemahaman konsep jika:

1) Sekurang-kurangnya $80 \%$ siswa melakukan aktivitas dalam kelompok.

2) Sekurang-kurangnya $80 \%$ hasil belajar siswa.

\section{HASIL PENELITIAN DAN PEMBAHASAN}

Berdasarkan Penilaian yang dilakukan oleh observer terhadap kinerja guru dalam membuat rencana perbaikan pembelajaran, melalui penggunaan pembelajan terpadu

Berdasarkan data hasil penelitian mengenai aktifitas belajar siswa dengan menggunakan media kartu berpasangan di kelas IV SD Negeri Kebagusan 02 Pagi Kecamatan Pasar Minggu Jakarta Selatan berhasil ditingkatkan, melalui upaya tindakan perencanaan dan pelaksanaan pembelajaran. Pada pelaksanaan ini dibatasi sampai siklus II Pertemuan 2. Hal ini didasarkan atas hasil perolehan siswa yang relatif sangat baik.

\section{A. Perencanaan}

Rencana guru dalam menyampaikan pembelajaran materi pokok konsep pengaruh perubahan lingkungan terhadap daratan sudah cukup baik sudah tepat, dan sudah sesuai dengan bahan ajar. Langkah-langkah guru dalam membuat Rencana Pelaksanaan Pembelajaran sudah baik, pengalokasian waktu yang dibuat benarbenar disesuaikan dengan waktu yang ada. Metode yang digunakan adalah ceramah bervariasi, tanya jawab, diskusi dan permainan kartu berpasangan.

Selain itu perencanaaan dalam mengumpulkan alat peraga sudah baik dan sesuai materi yang diajarkan. Agar alat peraga atau alat bantu tersebut dapat memberikan hasil yang maksimal bagi guru maupun bagi siswa, maka dalam pemilihan dan penggunaannya hendaknya direncanakan secara matang serta memperhatikan prinsip-prinsip sebagai berikut:

1. Menentukan jenis alat peraga yang tepat sesuai dengan tujuan dan bahan ajar.

2. Disesuaikan dengan tingkat kemampuan siswa.

3. Pelaksanaannya ditampilkan pada waktu yang tepat.

4. Sebelum digunakan harus ada kesiapan guru dan siswa.

5. Memperhatikan soal disiplin atau tata tertib, terutama dalam menjaga peralatan dan bahan yang digunakan.

6. Memperhatikan keamanan siswa.

\section{B. Pelaksanaan}

Pada penelitian ini dibatasi sampai siklkus kedua. Hal ini didasarkan atas hasil perolehan siswa yang relatif sudah baik. Dari hasil rangkaian pelaksanaan siklus I samapai siklus II menunjukan bahwa penggunaan media kartu berpasangan dalam pembelajaran Ilmu Pengetahuan Alam dapat meningkatkan aktifitas dan hasil belajar siswa.

Penggunaan media pembelajaran kartu berpasangan dapat menumbuh kembangkan sikap kreatif dan berpikir cepat dan tepat dalam memahami suatu materi. Pembelajarannya dilakukan secara santai dan sesuai dengan karakter siswa karena belajar sambil bermain. Sehingga siswa merasa tidak merasa jenuh atau bosan karena guru tidak mendominasi pembelajaran. Penggunaan kartu soal dan kartu jawabana sangat menarik perhatian siswa sehingga mereka merasa tertantang untuk kartu berpasangan yang benar.

Dari hasil penelitian ini pada dasarnya siswa dapat melaksanakan langkah-langkah pembelajaran dengan menggunakan media kartu berpasangan, namun masih ada beberapa siswa yang yang mengalami kesulitan dalam 
memberikan tanggapan mengenai permasalahanpermasalahan yang dihadapi. Hal ini disebabkan antara lain: (1) penggunaan media kartu berpasangan merupakan hal baru bagi siswa, (2) kurangnya minat siswa dalam membaca, dan (3) kemampuan guru dalam memberikan arahan dan motivasi.

Pada umumnya rangkaian pelaksanaan siklus tindakan menampakan adanya peningkatan proses dan hasil belajar yang lebih baik. Kegiatan belajar siswa melibatkan aktifitas fisik, sosial, emosional dan mental secara menyeluruh sehingga media ini tepat digunakan untuk meningkatkan aktifitas belajar siswa. Aktifitas belajar secara fisik dianataranya berperan aktif dalam mencari pasangan kartu, sehingga siswa tidak hanya duduk di kursi mendengarkan penjelasan dari guru. Aktifitas belajar secara sosial diantaranya adanya interaksi anatar siswa dalam mencocokan kartu yang dimilikinya sehingga terjadi komunikasi secara aktif antara siswa. Aktifitas siswa secara emosional juga meningkat karena dengan kartu yang mereka miliki siswa tertantang untuk kartu berpasangan nya sehingga siswa menjadi aktif dan kreatif. Dengan demikian mereka aktif secara mental karena berani bertanya dan menyampaikan pendapat. Berikut adalah nilai aktivitas siswa setiap siklus :

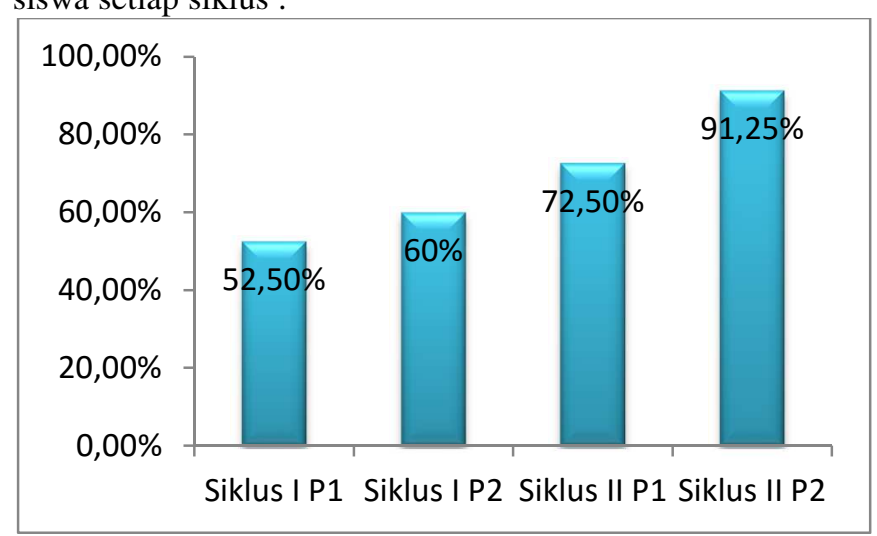

Gambar 1. Peningkatan Rata-rata Aktivitas Belajar Siswa Pada Setiap Siklus

Selain dapat meningkatkan aktifitas belajar siswa, media kartu berpasangan juga dapat meningkatkan hasil belajar siswa. Berikut adalah hasil belajar siswa untuk setiap siklus.

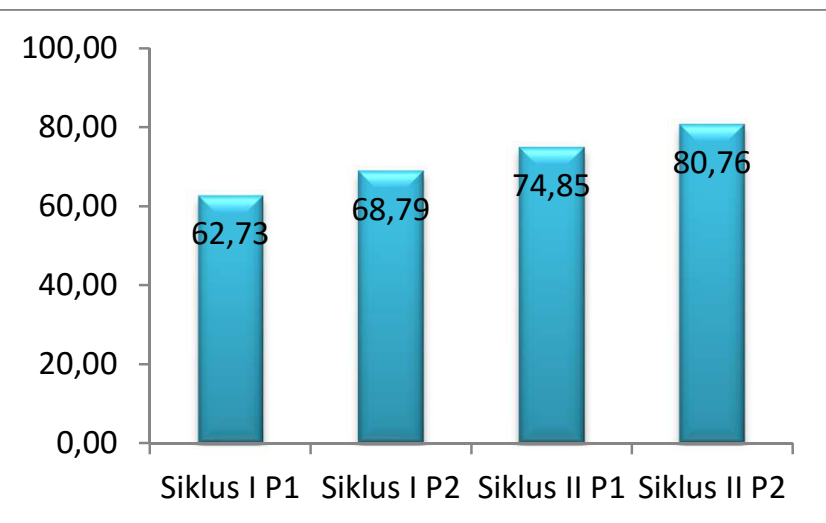

Gambar 2. Peningkatan Rata-rata Aktivitas Belajar Siswa Pada Setiap Siklus

\section{KESIMPULAN DAN SARAN}

Berdasarkan hasil penelitian Penggunaan media pembelajaran kartu berpasangan dalam melaksanakan pembelajaran di kelas IV SD Negeri Kebagusan 02 Pagi Kecamatan Pasar Minggu Jakarta Selatan dalam rangka perbaikan proses pembelajaran, yang telah dilaksanakan dapat diambil kesimpulan sebagai berikut:

1. Kemampuan guru membuat Rencana Pelaksanaan Pembelajaran pembelajaran Ilmu Pengetahuan Alam pada materi "Pengaruh Perubahan Lingkungan terhadap Daratan" dengan menggunakan media kartu berpasangan mengalami peningkatan. Hal itu ditunjukkan bahwa nilai kemampuan guru membuat Rencana Pelaksanaan Pembelajaran pada siklus I pertemuan 1 adalah 51\%, siklus I pertemuan 2 74,4\%, siklus II pertemuan $174,4 \%$, sedangkan pada siklus II Pertemuan 2 meningkat menjadi 82,7\%.

2. Kemampuan guru dalam melaksanakan pembelajaran Ilmu Pengetahuan Alam pada materi "Pengaruh Perubahan Lingkungan terhadap Daratan" dengan menggunakan media kartu berpasangan mengalami peningkatan. Hal itu ditunjukkan bahwa nilai kemampuan guru melaksanakan pembelajaran pada siklus I pertemuan 1 adalah $51,6 \%$, siklus I pertemuan $262,85 \%$, siklus II pertemuan $174,41 \%$, sedangkan pada siklus II Pertemuan 2 meningkat menjadi 85,96\%.

3. Pemahaman siswa tentang materi "Pengaruh Perubahan Lingkungan terhadap Daratan" di kelas IV SD Negeri Kebagusan 02 Pagi Kecamatan Pasar Minggu Jakarta Selatan mengalami peningkatan. Nilai rata-rata hasil belajar siswa yang didasarkan pada hasil evaluasi belajar siswa pada siklus I pertemuan 1 diperoleh nilai rata-rata 62,73 , siklus I pertemuan 2 dengan rata-rata 68,79 , siklus II pertemuan 1 meningkat menjadi 74,85 dan pada siklus II Pertemuan 2 diperoleh nilai rata-rata 80,76 .

Berdasarkan hasil penelitian penggunaan media pembelajaran kartu berpasangan dalam melaksanakan pembelajaran di kelas IV SD Negeri Kebagusan 02 Pagi Kecamatan Pasar Minggu Jakarta Selatan dalam rangka 
perbaikan proses pembelajaran, yang telah dilaksanakan, dapat dikemukakan saran sebagai berikut:

1. Penggunaan media kartu berpasangan dapat dijadikan salah satu alternatif media pembelajaran yang dapat digunakan oleh guru dalam rangka peningkatan hasil belajar siswa. Guna mempersiapkan hasil yang baik, media kartu berpasangan hendaknya dipersiapkan secara lebih matang dan tetap mempertimbangkan kemampuan, minat, dan kebutuhan siswa.

2. Guna mengatasi berbagai masalah yang dihadapi dalam pembelajaran, khususnya dalam menghadapi permasalahan yang bersifat klasikal, diharapkan guru dapat mengimplementasikan Penelitian Tindakan Kelas sebagai solusinya dan menjadikan Penelitian Tindakan Kelas sebagai salah satu tradisi profesi sebagai upaya meningkatkan mutu pendidikan yang merupakan tanggung jawab profesi guru.

3. Peran guru sebagai fasilitator harus lebih ditingkatkan lagi agar dicapai hasil yang maksimal.

\section{DAFTAR PUSTAKA}

[1] [Ali, Muhammad (1983). Guru dalam Proses Belajar Mengajar. Bandung: Sinar Baru Algesindo.

[2] Asnawir, Delia (2002). Media Pembelajaran. Jakarta: Citra Utama.

[3] Cahyoto (1997). Dasar-Dasar Metodologi Penelitian, Malang : Lembaga Penelitian IKIP Malang..

[4] Carr, W. and Kemmis, S (1986). Becoming Critical: Education, Knowledge and Action Research. Falmer Press: Besingstoke, Hants.

[5] Darmodjo, Hendro dan Kaligis (1991). Pendidikan IPA II. Jakarta: Depdikbud Dirjen Pendidikan Tinggi Proyek Pembinaan Tenaga Kerja.

[6] Depdikbud (1994). Kurikulum Pendidikan Dasar. Jakarta: Depdikbud.

[7] _ (1999). Penilaian adalah Hasil Kerja Anak. Jakarta: Depdikbud.

[8] Depdiknas (2003). Kurikulum 2004 Standar Kompetensi Mata Pelajaran Ilmu Pengetahuan Alam Sekolah Dasar dan Madrasah Ibtidaiyah. Jakarta: Depdiknas.

[9] (2005). Kerangka Dasar Kurikulum 2006. Jakarta: Pusat Kurikulum Depdiknas

[10] Dimyati, dan Mujiono (1999). Belajar dan Pembelajaran. Jakarta: Rineka Cipta

[11] Hamalik, Oemar (1985). Pendekatan Baru Strategi Belajar Mengajar. Bandung: Remaja Rosda Karya Alumni. (1994). Media Pendidikan. Jakarta:

Mengajar. Jakarta: Bumi Aksara $\quad$ Belajar

[14] Hakim, Tursan (2005). Belajar Secara Efektif. Jakarta: Puspa Swara.

[15] Ibrahim, Muslimin, dkk (2000). Pembelajaran Kooperatif. Surabaya: UNESA Press

[16] Kasbollah, Kasihani E.S (1998). Penelitian Tindakan Kelas (PTK). Jakarta: Dikti. Proyek Pendidikan Guru Sekolah Dasar.

[17] Kemmis, Stephen dan Robin Mc Taggart (1982). The Action-Research Planner. Victoria: Deakin University.

[18] Lie, Anita (2005). Cooperative Learning. Jakarta: Gramedia

[19] Mudjito, AK (1994). Belajar \& Pembelajaran 2. Jakarta: Pusat Penerbitan Universitas Terbuka.

[20] Mulyana, Edi Hendri (2008). Pendidikan dan Pembelajaran IPA di Sekolah Dasar. Tasikmalaya: Buku Wajib Perkuliahan IPA PGSD UPI Kampus Tasikmalaya.

[21] Nasution, S (1984). Berbagai Pendekatan dalam Proses Belajar Mengajar. Jakarta: Bumi Aksara.

[22] Rochmadi, Dudi (1997). Evaluasi Pembelajaran. Jakarta: Depdiknas.

[23] Siddiq, M. Djauhar, dkk (2008). Pengembangan Bahan Pembelajaran SD. Jakarta: Dirjen Dikti Depdiknas.

[24] Slameto (2003). Belajar dan Faktor-faktor yang Mempengaruhinya. Jakarta: PT Rineka Cipta

[25] Sudjana, Nana (2004). Dasar-dasar Proses Belajar Mengajar. Bandung: Sinar Baru Algensindo.

[26] Surya, Muhammad (2003). Psikologi Pembelajaran dan Pengajaran. Bandung:Yayasan Bhakti Winaya.

[27] Syah, Muhibbin (2002). Psikologi Pendidikan dengan Pendekatan Baru. Bandung: Remaja Rosdakarya.

[28] Tim Penyusun Kamus Pusat Bahasa (2008). Kamus Besar Bahasa Indonesia (KBBI). Jakarta: Pusat Bahasa

[29] Wahyono, Budi (2008). Ilmu Pengetahuan Alam 4. Jakarta: Pusat Perbukuan Depdiknas.

[30] Usman, Moh. Uzer (1994). Menjadi Guru Profesional. Bandung: Remaja Rosdakarya. 